\title{
Design of a Polymerase Chain Reaction for Specific Detection of Corn Stunt Spiroplasma
}

Thereza S. L. Barros, USDA-ARS, Molecular Plant Pathology Laboratory, Beltsville, MD 20705, and Laboratório de Biologia Molecular, Departamento de Biologia Celular, Universidade de Brasília, Brasília, DF, 70919-970, Brazil; Robert E. Davis, USDA-ARS, Molecular Plant Pathology Laboratory, Beltsville, MD 20705; Renato 0. Resende, Laboratório de Virologia e Microscopia Eletrônica, Departamento de Biologia Celular, Universidade de Brasília, Brasília, DF, 70919-970, Brazil; and Ellen L. Dally, USDA-ARS, Molecular Plant Pathology Laboratory, Beltsville, MD 20705

\begin{abstract}
Barros, T. S. L., Davis, R. E., Resende, R. O., and Dally, E. L. 2001. Design of a polymerase chain reaction for specific detection of corn stunt spiroplasma. Plant Dis. 85:475-480.

Corn stunt disease is a major limiting factor in production of corn (Zea mays) in the Americas. To develop a polymerase chain reaction (PCR) assay specific for detection of the causal agent, Spiroplasma kunkelii, PCR primers were designed on the basis of unique regions of the nucleotide sequence of the $S$. kunkelii spiralin gene. DNA was amplified in PCRs containing template DNAs derived from laboratory strains of $S$. kunkelii and from naturally diseased corn plants collected in the field. No DNA amplification was observed in PCRs containing template DNAs derived from other Spiroplasma species tested or from healthy corn or corn infected by maize bushy stunt phytoplasma. The availability of a sensitive and specific PCR for detection and identification of $S$. kunkelii should facilitate studies of the ecology of this pathogen, as well as its influence in the incidence, spread, and severity of corn stunting diseases.
\end{abstract}

Additional keywords: CSS, Maize rayado fino virus, mollicutes

In 1968, mycoplasmalike organisms were reported in corn stunt-diseased (Zea mays L.) plants and in corn stunt-infected insect vectors $(17,25)$. The cell wall-less microorganism associated with Rio Grande corn stunt was subsequently found to be helical and motile and to represent an entirely new group of pathogens, for which the term "spiroplasma" was coined $(11,12)$. Cultivation of the organism in vitro permitted researchers to gain conclusive evidence that this spiroplasma is the causal agent of Rio Grande corn stunt $(3,32)$ and to describe the corn stunt spiroplasma (CSS) as a new species, Spiroplasma kunkelii (31).

In addition to $S$. kunkelii, several unrelated pathogens, including a virus and a phytoplasma, are responsible for inducing "corn stunt-like" symptoms in corn $(8,28)$. Thus, the term "corn stunt" has been restricted by various authors to that disorder caused by the spiroplasma $S$. kunkelii $(1,6,8,31)$. Traditionally, this disease has

Corresponding author: Robert E. Davis

E-mail: davisr@ba.ars.usda.gov

Accepted for publication 16 January 2001.

Publication no. D-2001-0228-01R

This article is in the public domain and not copyrightable. It may be freely reprinted with customary crediting of the source. The American Phytopathological Society, 2001. been known as the Rio Grande corn stunt or as pale stunt, depending upon geographic region $(2,8,29)$. Typical symptoms of this disease include chlorotic stripes, stunting, and sometimes reddening of leaves; but symptoms can be variable depending on the host genetic background and environmental conditions (27). Variability in symptoms, as well as the frequent presence in the field of corn stunting diseases caused by other pathogens, renders diagnosis unreliable when it is based on symptomatology alone. Corn stunt spiroplasmal disease is one of three major components of the corn stunt disease complex, a complex of disorders caused by $S$. kunkelii, maize bushy stunt phytoplasma (MBS), and Maize rayado fino virus (MRFV) (28). This complex is a major constraint to corn (maize) production in the Americas, and its incidence has increased recently in parts of Central and South America, including Brazil $(18,22,29)$. Correct diagnosis of disease in the field, including attribution of predominant symptom syndromes to specific pathogens or to mixed pathogen infections, is critical for devising effective measures to mitigate damaging effects of the corn stunt disease complex.

In addition to observation of symptoms, several methods for pathogen detection have been used to aid in the diagnosis of corn stunt disease caused by S. kunkelii. Of these, serological methods have been the most broadly applicable and have been effectively used in assessing the presence of CSS in maize in the field $(1,16,29)$. The polymerase chain reaction (PCR) offers advantages such as exceptional sensitivity for the detection of plant pathogens $(13,21)$, and PCR primers have been designed for specific detection of other cornstunting pathogens, i.e., MBS phytoplasma (20) and MRFV (19). However, no PCRbased assay has been published for the specific detection and identification of $S$. kunkelii. To address this deficiency, we investigated spiralin genes as candidate sequences for the design of primers specific for S. kunkelii. Spiralin is the major membrane protein of spiroplasmas, and the nucleotide sequences of spiralin genes from S. kunkelii and closely related group I $(10,33)$ spiroplasmas have been determined $(4,14,15)$. In this study, we wished to develop a PCR procedure for detection and identification of $S$. kunkelii that could be used in place of, or in conjunction with, other methods.

\section{MATERIALS AND METHODS}

Plant samples and strains of spiroplasma and phytoplasma. Samples consisting of symptomatic leaves were collected from five diseased plants of corn growing in a field in central Brazil and lyophilized after collection. Of the five plants sampled in Brazil, three (plants 1, 2, and 3) exhibited proliferation of ears; all plants exhibited abnormal reddening of leaves. Spiroplasma strains $S$. citri $\mathrm{R} 8 \mathrm{~A} 2^{\mathrm{T}}$ (ATCC 27556), IRAN, and Maroc G; $S$. kunkelii strains I747 (ATCC 29051) and E275C $^{\mathrm{T}}$ (ATCC 29320); S. phoeniceum strain $\mathrm{P}^{2} 0^{\mathrm{T}}$ (ATCC 43115); and $S$. insoli-

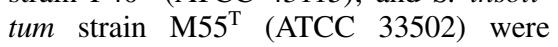
kindly provided by R. L. Jordan (USDAAgricultural Research Service, Beltsville, MD) (23). Strain S. kunkelii FL80 was kindly provided by M. J. Davis (University of Florida, Ft. Lauderdale) (6). S. melliferum G1 and $S$. kunkelii Nica were previously isolated in this laboratory (7). Samples of greenhouse-grown healthy corn and symptomatic corn that had been experimentally inoculated with CSS (S. kunkelii) or MBS phytoplasma (strain El Batan) were kindly provided by L. R. Nault (Ohio 
Agricultural Research and Development Center, Wooster).

DNA extraction. Template DNA for use in the PCR was extracted from plants of corn and from pure cultures of Spiroplasma species grown as previously described (24). The method of Prince et al. (30) was used for extraction of total nucleic acid from tissues of greenhousegrown corn and corn collected in the field in Brazil. For preparation of template from spiroplasma strains cultured in vitro, $1 \mathrm{ml}$ of fresh or frozen culture was centrifuged at $12,000 \times g$ for $30 \mathrm{~min}$. The pellet was resuspended in $400 \mu \mathrm{l}$ of TSE (10 $\mathrm{mM}$ Tris- $\mathrm{HCl}, 10 \mathrm{mM}$ EDTA, $10 \mathrm{mM}$ $\mathrm{NaCl}, \mathrm{pH}$ 8.0) buffer in a microfuge tube and frozen overnight. The resuspended pellet was thawed, $0.5 \%$ (final concentration) sodium dodecyl sulfate (SDS) and $0.4 \mathrm{mg}$ of proteinase $\mathrm{K}$ were added, and the mixture was incubated at $37^{\circ} \mathrm{C}$ for $30 \mathrm{~min}$. The mixture was then extracted twice with an equal volume of TE-saturated phenol (TE; $10 \mathrm{mM}$ Tris$\mathrm{HCl}, 1 \mathrm{mM}$ EDTA, pH 8.0) and once with chloroform/isoamyl alcohol (24:1 $\mathrm{vol} / \mathrm{vol})$, and centrifuged at $12,000 \times g$ for $5 \mathrm{~min}$. The upper aqueous phase was transferred to a clean tube, and the nucleic acids were precipitated by addition of 2.5 volumes of cold ethanol. Nucleic acids were pelleted by centrifugation at $12,000 \times g$ for $20 \mathrm{~min}$, washed with $70 \%$ ethanol, resuspended in $50 \mu \mathrm{l}$ of sterile water, and stored at $4^{\circ} \mathrm{C}$.

Nucleotide sequence accession numbers and alignments. To design the primers for specific detection of S. kunkelii, the nucleotide sequences of spiralin genes from nine strains of four Spiroplasma species, all belonging to group I, were aligned using the Clustal Method in the MegAlign option of DNASTAR program (DNASTAR, Inc., Madison, WI). The complete spiralin gene sequences were obtained from GenBank (National Center for Biotechnology Information, National Library of Medicine, Bldg. 38A, Bethesda, MD
20894) for $S$. citri strains Corse, 78, Alcanar 254, Israel/Asp1, Palmyre, and R8A2B; S. melliferum strain $\mathrm{BC}^{\mathrm{T}} ;$ S. kunkelii strain $\mathrm{E} 275^{\mathrm{T}}$; and $S$. phoeniceum strain $\mathrm{P} 40^{\mathrm{T}}$. The GenBank accession numbers are listed in Table 1.

PCR primers and conditions. In addition to the six primers designed in this study to prime the amplification of DNA from S. kunkelii, we used primer pair MBSF1/R1 (20) for the amplification of DNA specifically from MBS phytoplasma. PCR was performed in mixtures containing $1 \mu \mathrm{l}$ of DNA (20 to $200 \mathrm{ng}$ ), $200 \mu \mathrm{M}$ each $\mathrm{dNTP}$ and $0.4 \mu \mathrm{M}$ each primer. The PCRs were carried out in a final volume of $50 \mu \mathrm{l}$ for 35 cycles in an automated thermocycler (Perkin Elmer DNA Thermal Cycler 480, Branchburg, NJ). The following parameters were used: denaturation for 1 min (2 min for the first cycle) at $94^{\circ} \mathrm{C}$, annealing for $2 \mathrm{~min}$ at $60^{\circ} \mathrm{C}$, and primer extension for $3 \mathrm{~min}\left(10 \mathrm{~min}\right.$ in the final cycle) at $72^{\circ} \mathrm{C}$. PCR products were analyzed by electrophoresis through a $1 \%$ agarose gel followed by staining in ethidium bromide and visualization of DNA bands using a UV transilluminator.

Nucleotide sequencing of PCR products. DNA products amplified in PCRs were sequenced using automated DNA sequencing (thermocycle sequencing, PerkinElmer/Applied Biosystem's AmpliTaq-FS DNA polymerase). To verify that the amplified DNAs were derived from the target spiralin gene sequences, the sequences of amplified DNA were aligned with $S$. kunkelii spiralin gene sequence (GenBank U57659) using Align option of DNASTAR program.

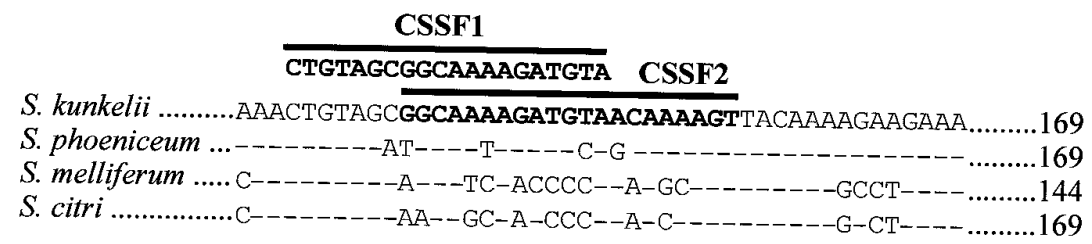

\section{CSSR5}

S. kunkelii ......... AAGTAGCCGATGTAACAAATGTTACAAAAACTGAATTAGAATTAG .........505

S. phoeniceum ... ----- G-A--CC-CA-GCC--------A-_---_--GC--.........493

S. melliferum .....---CTT-AACCCC--A-GCA----A----GA---G---A-TGC-- ..........480

S. citri .................--- C---A-- CCC--A-C-A-------- $\mathrm{GA}---\mathrm{G}---\mathrm{A}-\mathrm{TGC}-\mathrm{A}$..........493

\section{CSSR1}

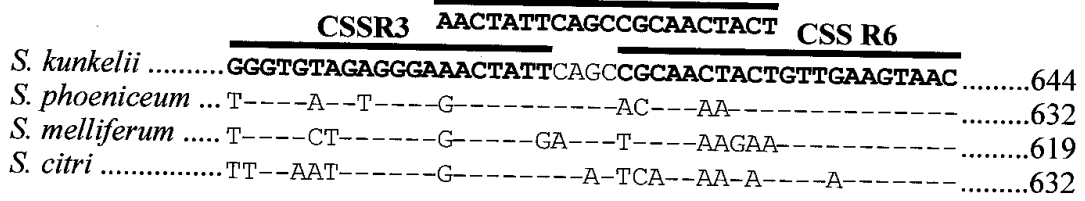

Fig. 1. Annealing positions of polymerase chain reaction primers in aligned spiralin gene sequences from Spiroplasma kunkelii, S. phoeniceum, S. melliferum, and S. citri. Three regions of sequence variability are shown. Dashes indicate bases identical to those in the spiralin gene sequence from $S$. kunkelii. Base positions were numbered from the beginning of the spiralin gene coding region; numbers indicate positions of the last base in each sequence fragment. Designations for six different primers are CSSF1, CSSF2, CSSR1, CSSR3, CSSR5, and CSSR6.

Table 1. Sequence similarities among spiralin genes from Spiroplasma species

\begin{tabular}{|c|c|c|c|c|c|c|c|c|}
\hline \multirow{2}{*}{$\begin{array}{l}\text { Spiralin gene sequence } \\
\text { (GenBank no.) }\end{array}$} & \multicolumn{8}{|c|}{ Sequence similarity (\%) with indicated spiroplasma strain DNA } \\
\hline & $\mathbf{P 4 0}^{\mathrm{T}}$ & $\mathbf{B C 3}^{\mathrm{T}}$ & Palmyre & R8A2B & Corse & 78 & Israel/Asp1 & Alcanar 254 ${ }^{\mathrm{a}}$ \\
\hline $\begin{array}{l}\text { S. kunkelii strain E275 } \\
\text { (U57659) }\end{array}$ & 88.1 & 76.7 & 73.5 & 73.3 & 74.1 & 73.7 & 73.7 & 73.5 \\
\hline $\begin{array}{l}\text { S. phoeniceum strain } \mathrm{P}^{4} 0^{\mathrm{T}} \\
\text { (U57659) }\end{array}$ & & 77.6 & 76.5 & 76.9 & 77.5 & 77.1 & 77.2 & 76.9 \\
\hline $\begin{array}{l}\text { S. melliferum strain } \mathrm{BC}^{\mathrm{T}} \\
\text { (M59366) }\end{array}$ & & & 84.7 & 86.5 & 86.7 & 85.4 & 85.6 & 85.3 \\
\hline $\begin{array}{l}\text { S. citri strain Palmyre } \\
\text { (U13997) }\end{array}$ & & & & 94.4 & 95.3 & 94.5 & 94.6 & 94.5 \\
\hline $\begin{array}{l}\text { S. citri strain R8A2B } \\
\text { (U13998) }\end{array}$ & & & & & 99.1 & 97.3 & 97.6 & 97.4 \\
\hline $\begin{array}{l}\text { S. citri strain Corse } \\
\text { (U13995) }\end{array}$ & & & & & & 98.5 & 98.7 & 98.5 \\
\hline $\begin{array}{l}\text { S. citri strain } 78 \\
\text { (U13993) }\end{array}$ & & & & & & & 99.9 & 99.7 \\
\hline $\begin{array}{l}\text { S. citri strain Israel/Asp1 } \\
\text { (U13996) }\end{array}$ & & & & & & & & 99.9 \\
\hline
\end{tabular}

a Alcanar 254, S. citri strain Alcanar 254 (GenBank accession number U13994). 


\section{RESULTS}

Sequence alignments and design of primers for PCR. The alignment of nucleotide sequences of spiralin genes from nine strains of four Spiroplasma species in group I revealed variable regions as well as highly conserved regions (data not shown). Spiralin gene sequence similarities among the four Spiroplasma species ranged from 73.3 to $88.1 \%$ (Table 1 ). On the basis of unique regions in the $S$. kunkelii spiralin gene sequence, six primers were designed. The primers, two forward (CSSF1 and CSSF2) and four reverse (CSSR1, CSSR3, CSSR5, and CSSR6), were used in five different paired combinations (CSSF1/R1, CSSF1/R3, CSSF1/R5, CSSF2/R5, and CSSF2/R6) that were selected based on results from preliminary experiments. The primer sequences are:

CSSF1, 5'-CTGTAGCGGCAAAAGATGTA-3' CSSF2, 5'-GGCAAAAGATGTAACAAAAGT-3' CSSR1, 5'-AGTAGTTGCGGCTGAATAGTT-3' CSSR 3, 5'-AATAGTTTCCCTCTACACCC-3' CSSR5, $5^{\prime}$-CAGTTTTTGTAACATTTGTTAC- ${ }^{\prime}$ CSSR6, 5'-GTTACTTCAACAGTAGTTGCG-3'.

The annealing positions of the primer sequences are indicated in Figure 1.

Specificity of PCR for amplification of DNA from S. kunkelii. DNA was amplified from all strains of $S$. kunkelii tested in PCRs primed by the primers designed in this study. PCRs containing template DNA derived from any of the four S. kunkelii strains cultured in vitro yielded DNA products of approximately $0.5 \mathrm{kbp}$ when
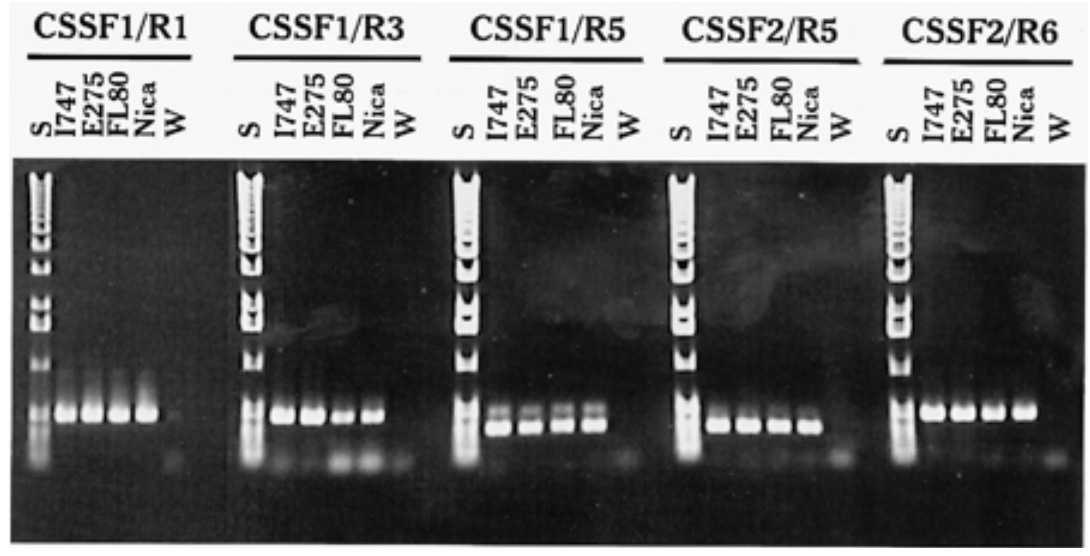

Fig. 2. Amplification of spiralin gene sequences from in vitro cultivated strains of Spiroplasma kunkelii in polymerase chain reactions (PCRs) primed by primer pairs CSSF1/R1, CSSF1/R3, CSSF1/R5, CSSF2/R5, and CSSF2/R6. Lanes I747, E275, FL80, and Nica; template DNA from $S$. kunkelii strains I747, E275 , FL80, and Nica, respectively. Lane W, reaction mixture devoid of template DNA; S, 1-kb ladder size standard. Sizes of DNA products were $0.5,0.5,0.35,0.35$, and 0.5 kbp in PCRs primed by primer pairs CSSF1/R1, CSSF1/R3, CSSF1/R5, CSSF2/R5, and CSSF2/R6, respectively. primed by primer pair CSSF1/R1, CSSF1/R3, or CSSF2/R6, and products of approximately $0.35 \mathrm{kbp}$ when primed by primer pair CSSF1/R5 or CSSF2/R5 (Fig. 2 ). The sizes of these products were as expected on the basis of the annealing positions of the primers in the spiralin gene.

DNA was amplified from corn that had been experimentally infected with CSS the DNA products were of the expected sizes when PCRs were primed by any of the five primer pairs (Fig. 3). Gel electrophoretic analysis of products of PCRs primed by CSSF1/R5 or by CSSF2/R5 revealed an additional, faint band, representing a DNA of approximately $0.5 \mathrm{kbp}$, larger than the expected size for DNA amplified in PCRs primed by these primer pairs (Fig. 3). This band was seen only in PCRs containing primer CSSR5 and was presumably due to nonspecific priming of DNA amplification from a different region of the genome.

No DNA amplification was observed in PCRs containing DNA derived from healthy corn or from corn infected by MBS phytoplasma (Fig. 3). The presence of MBS phytoplasma DNA templates in the PCR was demonstrated by the amplification of a $0.7 \mathrm{kbp}$ DNA sequence in reactions primed by primer pair MBSF1/R1 (Fig. 3), a primer pair specific for amplification of MBS phytoplasma DNA (20). No DNA products were observed in PCRs primed by CSSF1/R1, CSSF1/R3, CSSF1/R5, CSSF2/R5, and CSSF2/R6 when template DNA was derived from other Spiroplasma species, including $S$. citri strains $\mathrm{R} 8 \mathrm{~A} 2^{\mathrm{T}}$, IRAN, and Maroc G; S. melliferum strain

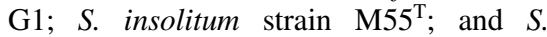
phoeniceum strain $\mathrm{P} 40^{\mathrm{T}}$ (Fig. 4).

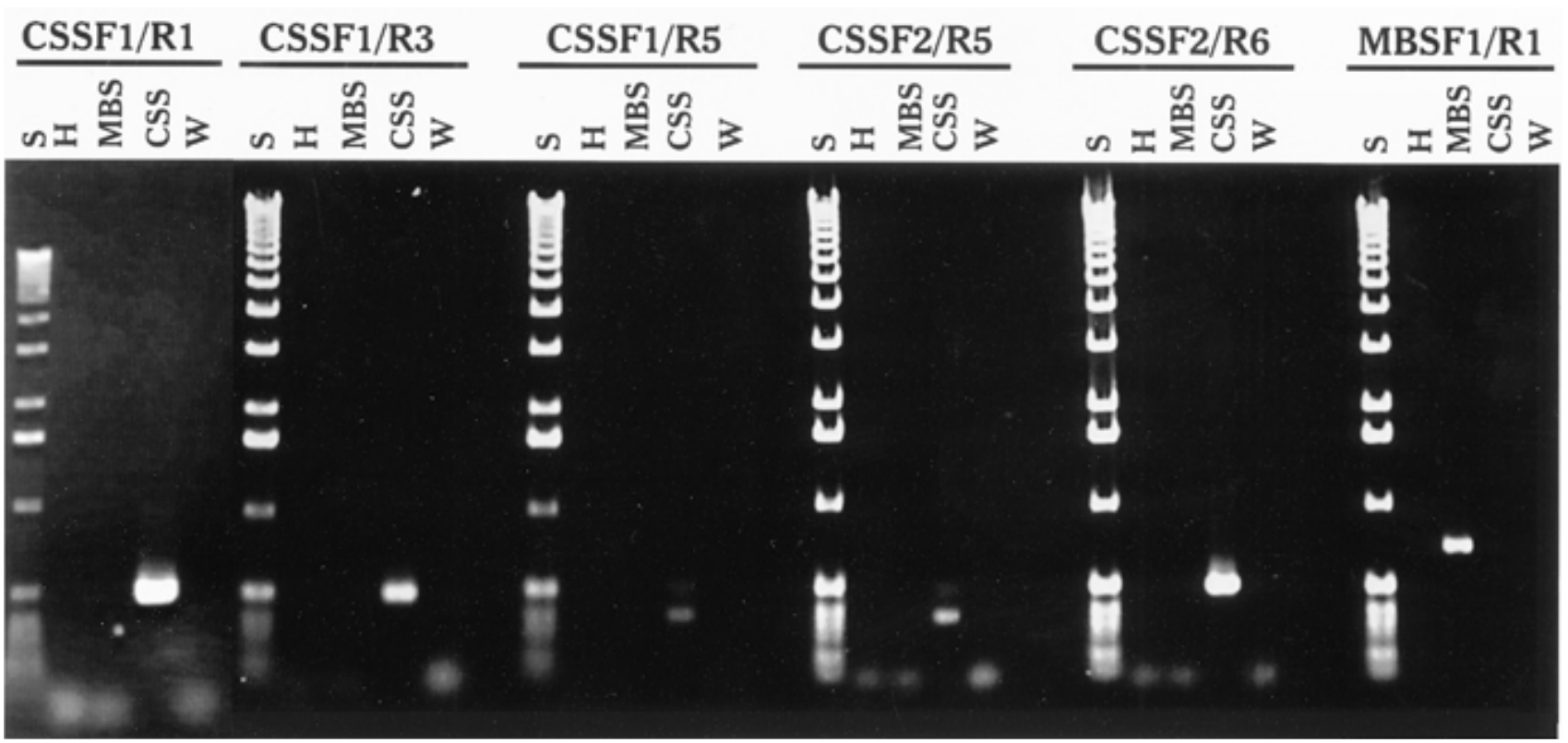

Fig. 3. Amplification of DNA sequences from experimentally inoculated greenhouse-grown corn plants infected by maize bushy stunt (MBS) phytoplasma or corn stunt spiroplasma (CSS), in polymerase chain reactions (PCRs) primed by primer pairs CSSF1/R1, CSSF1/R3, CSSF1/R5, CSSF2/R5, CSSF2/R6, or MBSF1/R1. Lane S, 1-kb ladder size standard; H, healthy corn; W, reaction mixture devoid of template DNA. Sizes of DNA products were 0.5, 0.5, 0.35, 0.35, 0.5, and $0.7 \mathrm{kbp}$ in PCRs primed by primer pairs CSSF1/R1, CSSF1/R3, CSSF1/R5, CSSF2/R5, CSSF2/R6, and MBSF1/R1, respectively. 
Sensitivity of $S$. kunkelii detection using PCR. When PCRs were primed by primer pair CSSF1/R5, CSS-specific DNA amplification was observed in reactions containing as little as $10 \mathrm{pg}$ of total DNA template from S. kunkelii strain I747 (Fig. 5). When PCRs were primed by primer pair CSSF1/R3, primer pair CSSF2/R5, or primer pair CSSF2/R6, DNA amplification was observed in reactions containing as little as $1 \mathrm{pg}$ of DNA template. When PCRs were primed by primer pair CSSF1/R1, DNA amplification was observed in reactions containing as little as $100 \mathrm{fg}$ of DNA template. These results indicate that detection of $S$. kunkelii was highly sensitive when PCRs were primed by any of several primer pairs (Fig. 5). The products of PCRs primed by CSSF1/R1, CSSF1/R3, and CSSF2/R6 were subjected to nucleotide sequence analysis. The nucleotide sequences of the DNA products shared $100 \%$ sequence similarity with the comparable region of the S. kunkelii spiralin gene (GenBank U57659).

Detection and identification of $S$. kunkelii and MBS phytoplasma in fieldcollected plant samples. Symptomatic, diseased plants of corn collected in the field in Brazil were assayed for the presence of S. kunkelii and MBS phytoplasma by the use of PCRs primed by primer pairs CSSF1/R1, CSSF1/R3, and CSSF2/R6 (all specific for $S$. kunkelii [this paper]) and MBSF1/R1 (specific for MBS phytoplasma [20]). Of five plants tested, three were found to be infected by MBS phytoplasma, and two were found to be infected by $S$. kunkelii. When PCRs were primed by primer pair MBSF1/R1, DNA amplification was observed in reactions containing template from plants 1,2 , and 3, indicating their infection by MBS phytoplasma; no DNA amplification was observed in reactions containing template from plants 4 and 5 (Fig. 6). By contrast, when PCRs were primed by primer pairs CSSF1/R1 and CSSF2/R6, DNA amplification was observed in reactions containing template from plants 4 and 5, indicating infection by S. kunkelii; whereas no DNA amplification was observed in reactions containing template from plants 1, 2, and 3 (Fig. 6). When PCRs were primed by primer pair CSSF1/R3, DNA amplification was observed in reactions containing template from plant 4 and not from plant 5 (Fig. 6). Thus, primer pairs CSSF1/R1 and CSSF2/R6 may be more suitable for use in assays of infection by $S$. kunkelii in the field.

\section{DISCUSSION}

This communication reports, for the first time, PCRs that are specific for detection and identification of the CSS (S. kunkelii), causal agent of the corn stunt disease. The amplification of $S$. kunkelii DNA from naturally diseased, field collected corn, as well as from experimentally inoculated plants of corn and from several S. kunkelii strains cultured in vitro, support the thesis that primer pairs CSSF1/R1 and CSSF2/R6 prime amplification of spiralin gene sequences from diverse strains of $S$. kunkelii. A PCR previously designed by Davis and Dally (9) was specific for group I spiroplasmas and distinguished plant pathogenic from non-plant pathogenic species; however, that PCR was not specific for CSS.

The design of $S$. kunkelii speciesspecific primers in the present study was made possible by the presence of sequence variable regions in the spiralin gene. The

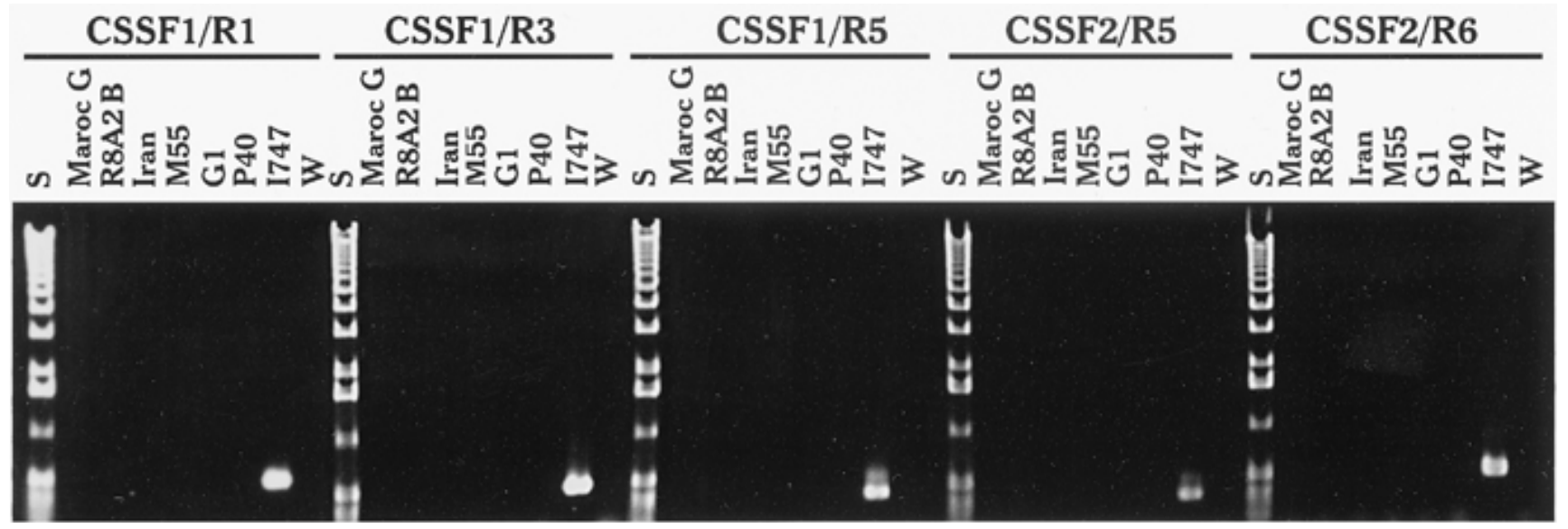

Fig. 4. Specificity of DNA amplification in polymerase chain reactions (PCRs) primed by primer pairs CSSF1/R1, CSSF1/R3, CSSF1/R5, CSSF2/R5, and CSSF2/R6. Template DNAs were derived from spiroplasma strains cultivated in vitro. R8A2B, Spiroplasma citri strain R8A2B; Maroc G, S. citri strain Maroc G; Iran, S. citri strain Iran; M55, S. insolitum strain M55T; G1, S. melliferum strain G1; P40, S. phoeniceum strain P40 ${ }^{\mathrm{T}}$; I747, S. kunkelii strain I747. Lane W, reaction mixture devoid of template DNA; S, 1-kb ladder size standard. Sizes of DNA products were $0.5,0.5,0.35,0.35$, and $0.5 \mathrm{kbp}$ in PCRs primed by primer pairs CSSF1/R1, CSSF1/R3, CSSF1/R5, CSSF2/R5, and CSSF2/R6, respectively.

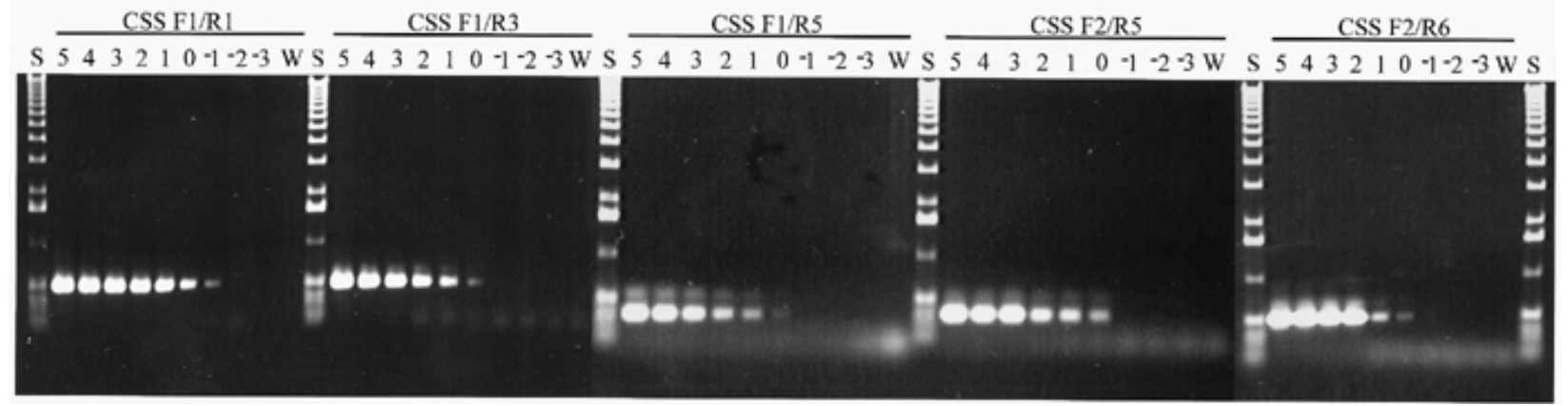

Fig. 5. Sensitivity of polymerase chain reactions (PCRs) for detection of corn stunt spiroplasma. PCRs were primed by Spiroplasma kunkelii-specific primer pairs CSSF1/R1, CSSF1/R3, CSSF1/R5, CSSF2/R5, and CSSF2/R6. Template DNA was derived from S. kunkelii strain I747. Lanes 5 through -3, $\log _{10}$ of the amount (pg) of template DNA per reaction. Lane W, reaction mixture devoid of template DNA; S, 1-kb ladder size standard. Sizes of DNA products were $0.5,0.5,0.35,0.35$, and $0.5 \mathrm{kbp}$ in PCRs primed by primer pairs CSSF1/R1, CSSF1/R3, CSSF1/R5, CSSF2/R5, and CSSF2/R6, respectively. 
spiralin gene sequence variability across different species should similarly make it possible to design primers specific for the detection and identification of other group I spiroplasma species such as $S$. citri, $S$. phoeniceum, and S. melliferum.

Methods most often used for the detection and identification of CSS in its hosts have been based on serology, which requires an available supply of consistent, high-quality antibodies (polyclonal antisera or monoclonal antibodies) $(10,16,23)$. Advantages of PCR for detection and identification of the spiroplasma include the known high sensitivity of PCR for pathogen detection, reproducibility of key reagents (e.g., primers), and the potential for using PCR or reverse transcription (RT)PCR to detect and identify the three major pathogen components of the corn stunt disease complex (viz., CSS, MBS phytoplasma, and MRFV). The availability of primer pairs such as CSSF1/R1 and CSSF2/R6 for the specific and sensitive detection of CSS enables a PCR assay comparable to those currently used in the detection of the MBS phytoplasma (20) and MRFV (19) in corn and insect vectors. Further, CSS-specific PCR would be advantageous for distinguishing the CSS if another spiroplasma has the potential to infect corn and for studies of spiroplasma species interactions in a common host, such as Catharanthus roseus. In addition, since many species of spiroplasmas inhabit insects, availability of a PCR specific for CSS could be critical in large-scale screening of insects for identification and monitoring of potential vectors of CSS.

As noted above, CSS, MBS phytoplasma, and MRFV collectively induce in corn an economically important stunting disease complex (28). This disease com- plex currently is of growing concern in parts of South and Central America, including Brazil (18,22,26,29). Disease symptoms under different field conditions and in different regions have been variable. Investigations of the continuing spread and increased severity of this disease complex have frequently been unable to correlate a specific symptom with infection by a specific pathogen. In Brazil, two major diseases that are part of the corn stunting disease complex are commonly referred to as pale stunt and red stunt $(5,29)$. In recent outbreaks, CSS has been reported in association with pale stunt $(26,29)$, and MBS phytoplasma has been reported in association with red stunt $(2,26,29)$. However, MBS phytoplasma may not be the only pathogen capable of inducing leaf reddening and stunting in corn in Brazil. The availability of a specific and sensitive assay for detection of CSS should facilitate the study of the ecology of this pathogen, as well as its influence on the incidence, spread, and severity of the stunting disease complex. In addition, specific detection methods for the three components of this complex could support breeding programs that are aimed at obtaining corn with multiple resistances to corn stunt, maize bushy stunt, and maize rayado fino diseases.

\section{ACKNOWLEDGMENTS}

Presented as part of the doctorate thesis of T. S. L. Barros. T. S. L. Barros was a visiting scientist in the Molecular Plant Pathology Laboratory, USDA-ARS, Beltsville, MD, under a fellowship from National Research Council of Brazil (CNPq). We gratefully acknowledge Elizabeth Oliveira for collecting field samples and Kristi Bottner for technical assistance.

\section{LITERATURE CITED}

1. Bajet, N. B., and Renfro, B. L. 1989. Occurrence of corn stunt spiroplasma at different

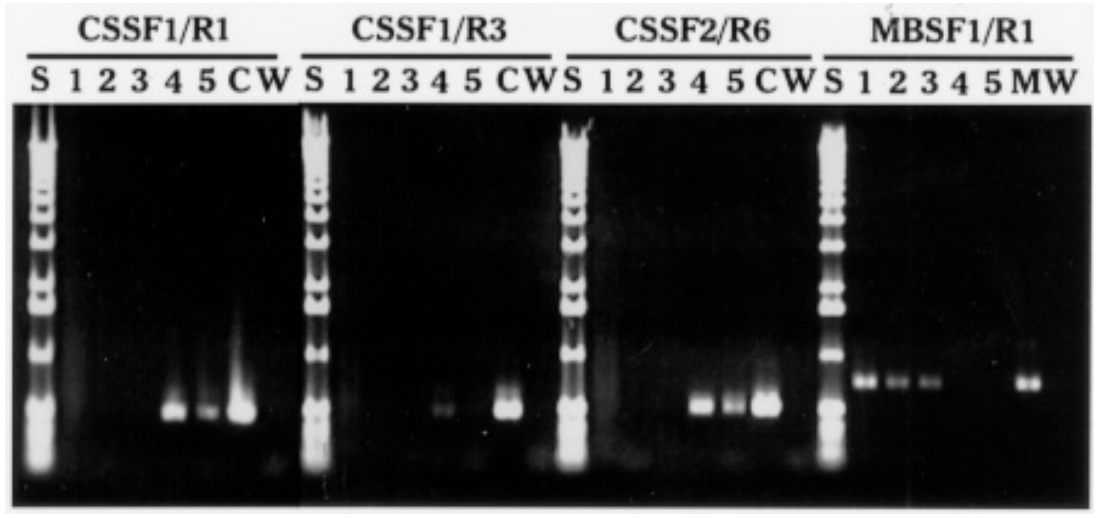

Fig. 6. Detection and identification of Spiroplasma kunkelii and maize bushy stunt phytoplasma in symptomatic plants of corn collected in the field in Brazil by the use of polymerase chain reactions (PCRs) primed by primer pairs CSSF1/R1, CSSF1/R3, and CSSF2/R6 for amplification of corn stunt spiroplasma (CSS) DNA and primer pair MBSF1/R1 for amplification of maize bushy stunt phytoplasma (MBS) DNA. Lanes 1 through 5, products of PCRs containing template DNAs derived from five diseased corn plants numbered 1 through 5 , respectively. Lane C, control PCR containing DNA from a greenhouse-grown corn plant experimentally inoculated with S. kunkelii; M, control PCR containing DNA from a greenhouse-grown corn plant experimentally inoculated with maize bushy stunt phytoplasma. Lane W, reaction mixture devoid of template DNA; S, 1-kb ladder size standard. Sizes of DNA products were $0.5 \mathrm{kbp}$ in PCRs primed by primer pairs CSSF1/R1, CSSF1/R3, CSSF2/R6, and $0.7 \mathrm{kbp}$ in PCRs primed by primer pair MBSF1/R1.

elevations in Mexico. Plant Dis. 73:926-930.

2. Bedendo, I. P., Davis, R. E., and Dally, E. L. 2000. Detection and identification of the maize bushy stunt phytoplasma in corn plants in Brazil using PCR and RFLP. Int. J. Pest Manage. 46:73-76.

3. Chen, T. A., and Liao, C. H. 1975. Corn stunt spiroplasma: Isolation, cultivation and proof of pathogenicity. Science 188:1015-1017.

4. Chevalier, C., Saillard, C., and Bové, J. M. 1990. Spiralins of Spiroplasma citri and Spiroplasma melliferum: Amino acid sequences and putative organization in the cell membrane. J. Bacteriol. 172:6090-6097.

5. Costa, A. S., Kitajima, E. W., and Arruda, S. C. 1971. Moléstias de vírus e de micoplasmas no milho em São Paulo. Rev. Soc. Bras. Fitopatol. 4:39-41.

6. Davis, M. J., Tsai, J. H., and McCoy, R. E. 1984. Isolation of the corn stunt spiroplasma from maize in Florida. Plant Dis. 68:600-604.

7. Davis, R. E. 1978. Spiroplasmas from flowers of Bidens pilosa L. and honey bees in Florida: Relationship to honey bee spiroplasma AS576 from Maryland. Phytopathol. News 12:67.

8. Davis, R. E., Chen, T.-A., and Worley, J. F. 1981. Corn stunt spiroplasma. Pages 40-50 in: Virus and Viruslike Diseases of Maize in the United States. D. T. Gordon, J. K. Knoke, and G. E. Scott, eds. South. Coop. Ser. Bull. 247.

9. Davis, R. E., and Dally, E. L. 1998. Distinction of plant pathogenic Spiroplasma species based on nucleotide sequences homologous with spiroplasmavirus SVTS2 DNA. Phytopathology 88:S20.

10. Davis, R. E., Lee, I.-M., and Basciano, L. K. 1979. Spiroplasmas: Serological grouping of strains associated with plants and insects. Can. J. Microbiol. 25:861-866.

11. Davis, R. E., and Worley, J. F. 1973. Spiroplasma: Motile, helical, microorganism associated with corn stunt disease. Phytopathology 63:403-408.

12. Davis, R. E., Worley, J. F., Whitcomb, R. F., Ishijima, T., Steere, R. L. 1972. Helical filaments produced by a mycoplasma-like organism associated with corn stunt disease. Science 176:521-523.

13. Eiras, M., Resende, R. O., and Ávila, A. C. 1998. Detection of plant viruses by the polymerase chain reaction. Fitopatol. Bras. 23:517.

14. Foissac, X., Bové, J. M., and Saillard, C. 1997. Sequence analysis of Spiroplasma phoeniceum and Spiroplasma kunkelii spiralin genes and comparison with other spiralin genes. Curr. Microbiol. 35:240-243.

15. Foissac, X., Saillard, C., Gandar, J., Zreik, L., and Bové, J. M. 1996. Spiralin polymorphism in strains of Spiroplasma citri is not due to differences in posttranslational palmitoylation. J. Bacteriol. 178:2934-2940.

16. Gordon, D. T., Nault, L. R., Gordon, N. H., and Heady, S. E. 1985. Serological detection of corn stunt spiroplasma and maize rayado fino virus in field-collected Dalbulus spp. from Mexico. Plant Dis. 69:108-111.

17. Granados, R. R. 1969. Electron microscopy of plants and insect vectors infected with the corn stunt disease agent. Contrib. Boyce Thompson Inst. 24:173-187.

18. Hammond, R. W., and Bedendo, I. P. 2001 Role of Maize rayado fino virus in the etiology of "red stunt" disease in Brazil. Plant Dis. 85:99.

19. Hammond, R. W., Kogel, R., and Ramirez, P. 1997. Variability of geographically distinct isolates of maize rayado fino virus in Latin America. J. Gen. Virol. 78:3153-3159.

20. Harrison, N. A., Richardson, P. A., Tsai, J. H., Ebbert, M. A., and Kramer, J. B. 1996. PCR assay for detection of the phytoplasma associated with maize bushy stunt disease. Plant 
Dis. 80:263-269.

21. Herson, J. M., and French, R. 1993. The polymerase chain reaction and plant disease diagnosis. Annu. Rev. Phytopathol. 31:81-109.

22. Hruska, A. J., and Peralta, M. G. 1997. Maize response to corn leafhopper (Homoptera: Cicadellidae) infestation and achaparramiento disease. J. Econ. Entomol. 90:604-610.

23. Jordan, R. L., Konai, M., Lee, I.-M., and Davis, R. E. 1989. Species-specific and crossreactive monoclonal antibodies to the plantpathogenic spiroplasmas Spiroplasma citri and S. kunkelii. Phytopathology 79:880-887.

24. Lee, I.-M., and Davis, R. E. 1984. New media for rapid growth of Spiroplasma citri and corn stunt spiroplasma. Phytopathology 74:84-89.

25. Maramorosch, K., Shikata, E., and Granados, R. R. 1968. Structures resembling mycoplasma in diseased plants and insect vectors. Trans. N.Y. Acad. Sci. Ser. 2. 30:841-855

26. Massola, N. S., Jr., Bedendo, I. P., Amorim, L., and Lopes, J. R. S. 1999. Quantificação de danos causados pelo enfezamento vermelho e enfezamento pálido do milho em condições de campo. Fitopatol. Bras. 24:136-142.

27. Nault, L. R. 1980. Maize bushy stunt and corn stunt: A comparison of disease symptoms, pathogen host ranges, and vectors. Phytopathology 70:659-662.

28. Nault, L. R. 1983. Origins in mesoamerica of maize viruses and mycoplasmas and their leafhopper vectors. Pages 259-266 in: Plant Virus Epidemiology. R. T. Plumb and J. M. Thresh, eds. Blackwell Scientific Publications, Oxford.

29. Oliveira, E., Waquil, J. M., Fernandes, F. T., Paiva, E., Resende, R. O., and Kitajima, E. W. 1998. "Enfezamento pálido" e "enfezamento vermelho" na cultura do milho no Brasil Central. Fitopatol. Bras. 23:45-47.

30. Prince, J. P., Davis, R. E., Wolf, T. K., Lee, I.M., Mogen, B. D., Dally, E. L., Bertaccini, A., Credi, R., and Barba, M. 1993. Molecular detection of diverse mycoplasmalike organ- isms (MLOs) associated with grapevine yellows and their classification with aster yellows, X-disease, and elm yellows MLOs. Phytopathology 83:1130-1137.

31. Whitcomb, R. F., Chen, T. A., Williamson, D. L., Liao, C., Tully, J. G., Bové, J. M. Mouches, C., Rose, D. L., Coan, M. E., and Clark, T. B. 1986. Spiroplasma kunkelii sp. nov.: Characterization of the etiological agent of corn stunt disease. Int. J. Syst. Bacteriol. 36:170-178.

32. Williamson, D. L., and Whitcomb, R. F. 1975. Plant mycoplasmas: A cultivable spiroplasma causes corn stunt disease. Science 188:10181020.

33. Williamson, D. L., Whitcomb, R. F., Tully, J. G., Gasparich, G. E., Rose, D. L., Carle, P., Bové, J. M., Hackett, K. J., Adams, J. R. Henegar, R. B., Konai, M., Chastel, C., and French, F. E. 1998. Revised group classification of the genus Spiroplasma. Int. J. Syst. Bacteriol. 48:1-12. 